Vol. 15 (2006): 152-165.

\title{
Polymer coated turnip rape seed did not facilitate early broadcast sowing under Finnish growing conditions
}

\author{
Pirjo Peltonen-Sainio, Hannu Känkänen, Katri Pahkala \\ MTT Agrifood Research Finland, Plant Production Research, FI-31600 Jokioinen, Finland, \\ e-mail: pirjo.peltonen-sainio@mtt.fi
}

Yrjö Salo

MTT Agrifood Research Finland, Plant Production Research, Toivonlinnantie 518, FI-21500 Piikkiö, Finland Erja Huusela-Veistola

MTT Agrifood Research Finland, Plant Production Research, FI-31600 Jokioinen, Finland

Jari Peltonen

Kemira GrowHow Ltd, PO Box 244, FI-02271 Espoo, Finland

\begin{abstract}
An alternative sowing time for summer turnip rape (Brassica rapa L. var. oleifera subvar. аппиa) and canola rape (Brassica napus L. var. oleifera subvar. апnиa) was investigated under northern European growing conditions, where the growing season is very short and seedling establishment in spring is difficult. Using a method termed carrier technology, seeds of spring canola were coated with polymer and sown in winter or early spring. Two types of polymer were tested: water-impervious Poligen ${ }^{\circledR}$ WE3 (polyethylene wax at five rates depending on experiment) and water-soluble, freeze sensitive Extender ${ }^{\circledR}$ (GrowTech at $3 \%$ of seed weight). Four separate field experiments at two locations (Jokioinen, $60^{\circ} 81^{\prime} \mathrm{N}$ and Mietoinen, $60^{\circ} 38^{\prime} \mathrm{N}$ ) and two laboratory experiments were carried out in 2002-2004. Early sowing times were used in combination with autumn control of weeds using non-selective herbicides and broadcast sowing onto cereal stubble to promote cost-efficiency. Such sowing method failed to produce even plant stands, as only few seedlings emerged. The polymer coatings were successful and the water-soluble, freeze sensitive polymer designed to allow an alternative sowing time performed well in laboratory tests. Large numbers of early sown coated and control seeds remained viable until the end of spring. Under field conditions germination or seedling establishment failed probably due to poor seed-to-soil contact. Moreover, unfavourable winter and spring conditions likely resulted in lack of synchrony between adequate temperature and water availability needed for seed imbibition and germination.
\end{abstract}

Key words: Brassica napus L. var. oleifera subvar. annua, Brassica rapa L. var. oleifera subvar. annиa, canola, emergence, establishment, germination, imbibition, polymer, seed coating, seeding date, seedling, temperature, viability 
Vol. 15 (2006): 152-165.

\section{Introduction}

Summer turnip rape (Brassica rapa L. var. oleifera subvar. аппиа) is the predominant oil crop grown in the northernmost areas of Europe because of its earliness in comparison with that of canola rape (Brassica napus L. var. oleifera subvar. апnиa) and other oil crops. Summer types are favoured due to harsh winter conditions: frosts and snow, and consequent recurrent problems of winter survival. Early maturity is required as night frosts in autumn interfere with seed ripening processes (Pahkala et al. 1991) resulting in high chlorophyll content in seed yield and reduced quality.

An alternative seeding date for spring canola was developed and introduced in Canada (Kirkland and Johnson 2000, Karamanos et al. 2002, Johnson and Ferguson 2004, Johnson et al. 2004, Wichman et al. 2004) to enable a longer growing period and to avoid unfavourable growing conditions. This was based on utilisation of exceptionally early spring growth. The method is also termed carrier technology: seeds of spring canola coated with polymer are sown during the preceding autumn (Kirkland and Johnson 2000, Johnson et al. 2004). The polymer used for coating 'carries' the unimbibed canola seeds over the unfavourable winter and early spring period. The coating polymer is designed to absorb water into the coat matrix while preventing water passage to seed (Zaychuk and Enders 2001). Although the premise of the polymer is to creature microfractures upon freezing, Willenborg observed this is not the case (C. Willenborg, personal communication 15 March 2006). As an alternative to autumn sowing, which in Finland likely faces problems of too moist soils for incorporation, coated canola seeds can be sown also earlier in the spring when night frosts still occur. In both cases, the only technically feasible method for alternative sowing time is to use broadcasting of the seeds.

Alternative sowing method is of interest also under northern European conditions, where not only is the growing season very short, but early summer drought often results in uneven seedling emergence (Pahkala et al. 1994). The uncertainty related to germination and seedling emergence is particularly emphasised in turnip rape, as small seeds are sown into the rapidly drying soil surface at about $2-3 \mathrm{~cm}$ depth. Unfavourable growing conditions, especially hot and dry conditions during flowering and seed set typical of Canadian prairies were, together with the short growing season, the original driving forces for developing carrier technology for spring canola (Kirkland and Johnson 2000). An alternative sowing time offers the additional benefit of reducing spring workload on farms.

The applicability of an alternative sowing time for summer turnip rape (and to lesser extent canola rape) using frost-breakable or water-impervious polymer seed coating was evaluated during three years of field experiments in Finland, representing the northernmost European growing conditions. In addition to applying the original Canadian innovation (Zaychuk and Enders 2001, Johnson et al. 2004), an alternative water-impervious coating material was studied to compare its capacity to prevent too early seed imbibition.

The original objectives of the investigations were: 1) to identify a seed coating material that resists too early imbibition of turnip rape seed when sown in early winter or spring, 2) to monitor costefficient management practices that sustain early and even crop establishment, and 3) to compare the development and growth of early sown turnip rape with that of a conventional May-sown crop. As problems were faced in securing seedling emergence when alternative broadcast sowing was used, the field studies were reduced and the behaviour of coating materials was further monitored by conducting germination tests with both intact seed samples and samples exposed to prevailing field conditions in winter and spring.

\section{Material and methods}

\section{Field experiments in 2002}

Field experiments were conducted at MTT Agrifood Research Finland, Jokioinen $\left(60^{\circ} 81^{\prime} \mathrm{N}\right)$ to 
Peltonen-Sainio, P. et al. An alternative sowing time for turnip rape under Finnish growing conditions

study the applicability of early spring sowing of summer turnip rape and canola rape in separate experiments. Experiment 1 (Exp. 1) included turnip rape and was conducted in a randomised complete block design with four replicates. The site was previously sown with barley (Hordeum vulgare L.), harvested in autumn 2001. Six treatments were compared and two turnip rape cultivars used: 1) cultivar Pouta control 2) seed coating of Pouta with water-impervious polymer, Poligen ${ }^{\circledR} \mathrm{WE} 3$ (polyethylene wax, Locquenghien et al. 2001) at $3 \%, 3)$ at $5 \%$, and 4 ) at $7 \%$ of seed weight, 5) cultivar Riikka control with Helix (insecticide thiamethoxam; fungicides metalaxyl-M, fludioxinil and difenoconazole) and 6) seed coating of Riikka with GrowTec Extender ${ }^{\circledR}$ (water soluble, freeze sensitive polymer coating, Zaychuk and Enders 2001) at $3 \%$ of seed weight with Helix application. Another experiment (Exp. 2) was arranged as randomised complete block design with canola rape cultivar Hyola with four replicates and five treatments: 1) control, 2) polymer seed coating with Poligen ${ }^{\circledR} \mathrm{WE} 3$ at $\left.3 \%, 3\right)$ at $\left.5 \%, 4\right)$ at $7 \%$, and 5) seed coating with GrowTec Extender ${ }^{\circledR}$ at $3 \%$.

Both Exp. 1 and Exp. 2 were sown using a plot seed drill (Øyjord plot drill, F. Walter \& Wintersteiger, Austria), with row distance set to $12.5 \mathrm{~cm}$, directly onto the barley stubble by keeping the coulters at ca. $15 \mathrm{~cm}$ above the soil surface. The targeted seeding rate was 350 viable seeds per square meter, which is commonly used in Finland. Plots of $8 \mathrm{~m} \times 1.25 \mathrm{~m}$ were sown on 5 April in 2002 (both experiments). Additional plots of 'Pouta' and 'Riikka' were sown at the end of each replicate in rotary harrowed soil at 2-3 cm soil depth without any polymer coating treatments. These plots were designed to serve as additional references for broadcast seeding. Similarly, control plots of 'Hyola' were sown adjacent to Exp. 2. These plots were sown at standard sowing time in spring, 13 May 2002. Plots were fertilised with $110 \mathrm{~kg} \mathrm{~N} \mathrm{ha}^{-1}$ by broadcasting on 24 April in early sown plots and at sowing in plots sown at the standard time. Weeds were not controlled. Flea beetles (Phyllotreta sp.) were controlled with Decis (deltamethrin $25 \mathrm{~g} \mathrm{l}^{-1}$ ) applied twice at $0.151 \mathrm{ha}^{-1}$ and once at $0.21 \mathrm{ha}^{-1}$. Furthermore, blossom beetles (Meligethes aeneus) were controlled with Decis (deltamethrin $25 \mathrm{~g} \mathrm{l}^{-1}$ ) applied twice at $0.41 \mathrm{ha}^{-1}$.

All the treatments in Exp. 1 and Exp. 2 were duplicated using an identical methodology in Mietoinen $\left(60^{\circ} 38^{\prime} \mathrm{N}\right)$ at MTT's Southwest Finland Research Station. Winter wheat (Triticum aestivum L.), harvested in autumn 2001 was the previous crop in Mietoinen. The experiments included also winter sowing without replications. Sowing dates in Mietoinen were: winter sowing on 14 December in 2001 (snow cower $1 \mathrm{~cm}$, air temperature $-1.1^{\circ} \mathrm{C}$ ). Early spring sowing was on 3 April in 2002 (temperature $0.0^{\circ} \mathrm{C}$ ) and standard spring sowing on 15 May 2002. In Mietoinen plots were fertilised with $120 \mathrm{~kg} \mathrm{~N} \mathrm{ha}^{-1}$ at sowing by broadcasting. Weeds were controlled with Trifulon $2.01 \mathrm{ha}^{-1}$ (trifluralin $1.02 \mathrm{~kg} \mathrm{ha}^{-1}$ ), flea beetles twice with Fastac 0.21 ha $^{-1}$ (alfa-sypermetrin $0.02 \mathrm{~kg} \mathrm{ha}^{-1}$ ) and blossom beetles with Karate WG $0.15 \mathrm{~kg} \mathrm{ha}^{-1}$ (lambdasyhalotrin $3.75 \mathrm{~g} \mathrm{ha}^{-1}$ ).

\section{Field experiment in 2002-2003}

The field experiment (Exp. 3) conducted at Jokioinen included summer turnip rape cultivar Valo. The experiment was conducted in a randomised complete block design with four replicates. Five treatments were compared: 1) control, seed coated with insecticide Cruiser (insecticide thiamethoxam; funcicides metalaxyl-M and fludioxinil), 2) seed coating with water-impervious polymer, Poligen ${ }^{\circledR}$ WE3 at $4 \%$ and Cruiser, 3) seed coating at $6 \%$ and Cruiser, 4) control, seed coated with insecticide Helix, and 5) seed coating with GrowTec Extender $^{\circledR}$ at $3 \%$ and Helix.

Oats (Avena sativa L.), harvested in autumn 2002 was the previous crop. The experiment was sown with an Øyjord plot drill directly onto the oat stubble as in Exps. 1 and 2. The targeted seeding rate was 350 viable seeds per square meter. Plots of $10 \mathrm{~m} \times 1.25 \mathrm{~m}$ were sown on 9 April in 2003 . Winter sowing was used as an additional reference without replicates. This took place on 14 November 2002 using a similar method as described for early spring sowing, except that the seeds were placed at $-5^{\circ} \mathrm{C}$ on $5-8 \mathrm{~cm}$ snow cover. Following 
poor seedling emergence no fertilisers and pesticides were applied.

The same treatments used in Exp. 3 were included using identical methodology in Mietoinen. Barley, harvested in autumn 2002, was the previous crop. Sowing dates in Mietoinen were: winter sowing on 12 December in 2002 (snow cover 5 $\mathrm{cm}$, air temperature $-0.1{ }^{\circ} \mathrm{C}$ ). Early spring sowing on 3 April in 2003 (air temperature $2.7^{\circ} \mathrm{C}$ ). Standard spring sowing was exceptionally late, on 11 June 2003 because of rainy weather. No fertilisers or weed control were applied due to poor seedling emergence. Blossom beetles were however controlled on with Fastac 0.21 ha $^{-1}$ (alfa-sypermetrin $0.02 \mathrm{~kg} \mathrm{ha}^{-1}$ ).

\section{Field experiments in 2003-2004}

Experiment 4, conducted at Jokioinen, was designed to study whether winter sowing of polymer coated turnip rape cultivar Valo resulted in improved seedling emergence given that the coated seeds have better contact with the soil, enabling imbibition in spring. The experiment was an additional test that was conducted without replicates, but in the case of success, it would have been repeated in the forthcoming years with proper experimental design. Half of the experimental area was autumn tilled prior to sowing (ca. $2 \mathrm{~cm}$ depth) with an S-tine harrow to have better premises for soil-to-seed contact, while the other half was nontilled and left with wheat stubble. Late autumn sowing into incorporated soil is possible only occasionally due to abundant precipitation typical for late autumns. Five treatments were sown across the tillage: 1) control coated with insecticide Cruiser, 2) seeds coated with water-impervious polymer, Poligen ${ }^{\circledR}$ WE3 at $4 \%$ and Cruiser, 3) seed coating at $6 \%$ and Cruiser, 4) control, seed coated with Helix, 5) seed coated with GrowTec Extend$\mathrm{er}^{\circledR}$ at $3 \%$ and Helix. An additional plot of winter turnip rape, cultivar Prisma, was sown on both autumn tilled soil and wheat stubble. Plots of $10 \mathrm{~m} \times$ $1.25 \mathrm{~m}$ were sown on 13 November 2003 and an exceptionally high seeding rate of 600 viable seeds per square meter was used.

\section{Measurements}

Seedling emergence was monitored in all field experiments (Exps. 1, 2, 3 and 4). Insect pests were monitored with yellow sticky traps and through visual observations. It was also planned to monitor seedling growth, time for full soil cover, flowering performance, changes in leaf area index with repeated measures, yield components, seed yield and chlorophyll and oil content of harvested yield. However, only in Exp. 1 seed yield was measured.

Additional laboratory experiments were carried out to determine why the alternative sowing times with polymer coatings were unsuccessful and especially to understand what happened to the sown seeds that did not emerge as seedlings. When early winter (November) and early spring (April) sowings of Exp. 3 took place, highly porous, non water-absorbing bags, each including 100 turnip rape seeds, were placed in the experimental field. Altogether 20 bags per treatment were prepared for winter sowing and 14 for early spring sowing. The bags were placed against soil to enable soil-toseed contact. This enabled evaluation of germination potential. In winter, half of the seed bags were covered by snow $(5-8 \mathrm{~cm})$ and half with straw shreds and snow. Also, in early spring, half of the bags were covered with straw shreds. The positions of seed bags were marked with sticks to ease their location later. Seed bags were collected nine times from winter sown treatments and six times from early spring sown treatments. At each sampling, one straw covered and one uncovered bag was collected. Each bag was opened in laboratory. Seeds were visually analysed and germinated seeds were counted. Non-germinated seeds were placed on moist blotting paper, covered with a glass cup with a hole in the top, and placed in a Jacobsen apparatus at a temperature of ca. $20^{\circ} \mathrm{C}$ (Lab-Exp. 1). Germinated seeds were counted 3, 5, 7,9 and 14 days after starting the germination test. Thereafter, non-germinated, hard seeds were carefully abraded with fine sandpaper, placed back in the Jacobsen apparatus on new moist blotting paper and observed 3, 5, and 7 days after abrasion. Remaining non-germinated, hard seeds were pricked once with a fine needle. They were re- 
turned to the Jacobsen apparatus and placed again on new moist blotting paper and observed 3, 5 and 7 days after pricking.

Another laboratory experiment (Lab-Exp. 2) was carried out on turnip rape cultivar Valo with three treatments: 1) control coated with insecticide Cruiser, 2) seed coating with water-impervious polymer, Poligen ${ }^{\circledR} \mathrm{WE} 3$ at $4 \%$ and Cruiser and 3 ) seed coating at $6 \%$ and Cruiser. All treatments were replicated three times. The experiment was done in growth chambers set at six temperatures $\left(2,5,7,10,15\right.$ and $\left.20^{\circ} \mathrm{C}\right)$ under conditions of darkness and $80 \%$ air humidity. One hundred seeds for each replicated treatment were placed on moist blotting paper in plastic Petri dishes (diameter $13 \mathrm{~cm}$ ). They were covered in such a way so as to allow gas exchange. Water was added to the Petri dishes when needed to maintain even water availability. Germinated seeds were counted frequently at one to five days intervals depending on progress of germination. At each counting, normal seedlings and seedlings with abnormal radicle or cotyledons were measured and removed as well as those infected with fungus. As no signs of germination were recorded at the last measurement, all the non-germinated seeds were transferred on to fresh blotting paper at room temperature in a Jacobsen apparatus (Copenhagen tank). Germinated, abnormal and fungus infected seeds were counted and removed over 14 days. Thereafter, remaining non-germinated, hard seeds were slightly rubbed with fine sandpaper, placed back in the Jacobsen apparatus on to changed, moist blotting paper and monitored 3, 5, and 7 days after rubbing. Remaining non-germinated, hard seeds were pricked once with a fine needle, put back into the Jacobsen apparatus on fresh, moist blotting paper and monitored 3, 5 and 7 days after pricking.

No analyses of variance were used because of lack of success of the sowing method in Exp. 1, 2 and 3 in both locations (Jokioinen and Mietoinen) and in addition to this, due to lack of both encouraging results and also replicates in Exp. 4. Treatment differences in germination (Lab-Exp. 2) were compared on the basis of standard deviations.

\section{Results and discussion}

\section{Applicability of alternative sowing time}

In this study we aimed at an alternative sowing time by combining seed coating method with broadcast sowing. We were well aware of the potential risk of inadequate soil-to-seed contact when using broadcast sowing - the traditionally used seeding method prior to agricultural mechanisation. Broadcast sowing is, however, likely to be the only frequently applicable sowing method in late autumn or early winter in Finland. Poor soil-toseed contact was also demonstrated to be a potential risk when polymer coated seeds were sown into hard, cold soil where incorporation was problematic (Kirkland and Johnson 2000, Willenborg et al. 2004). However, with spring snow melt the soil remains sufficiently moist for long periods for small turnip rape seed to imbibe. We also further developed the idea of providing sufficient moisture for germination by cutting straw after sowing to slightly cover the sown seeds. We used only smallscale demonstration areas, but this could be done on a larger scale in farmer's field by harvesting the preceding cereal at high stubble. After the surfacesowing the turnip rape seeds the stubble can be cut with a mower chopper to provide light cover to the seeds and to keep the soil surface moist for longer periods.

The alternative sowing time combined with ultimate low-cost management was not successful and only occasional if any seedlings emerged. Turnip rape was thought to be the best potential candidate for success in broadcast sowing combined with carrier technology, because it, together with canola rape, retains non-domesticated traits due to being a relatively young crop (Gruber et al. 2004). It is known to produce volunteers frequently and be a weed (Salonen et al. 2001, Gruber et al. 2004). Moreover, it can compensate for reduced seedling number through enhanced growth of emerged seedlings without marked reductions in seed yield (Pahkala and Sankari 2001).

The first year of experimentation (Exp. 1) was most successful. GrowTec Extender ${ }^{\circledR}$ coating per- 
Vol. 15 (2006): 152-165.

formed exceptionally well compared with later on, as roughly $55 \%$ of the plot area produced turnip rape and $22 \%$ rape when seeded in early spring (data not shown). No seedlings emerged when Poligen ${ }^{\circledR}$ was used at $7 \%$. For canola rape 'Hyola', the only harvestable yield followed application of GrowTec Extender ${ }^{\circledR}$ at 3\%, but seed yield was only some $200 \mathrm{~kg} \mathrm{ha}^{-1}$. On the harrowed area, Helix coated 'Riikka' yielded $1340 \mathrm{~kg} \mathrm{ha}^{-1}$ and uncoated 'Pouta' ca. $700 \mathrm{~kg} \mathrm{ha}{ }^{-1}$, while coated treatments were unable to establish any plant stands. When sown onto stubble, control and GrowTec Extend$\mathrm{er}^{\circledR}$ coated 'Riikka' yielded some $600-900 \mathrm{~kg} \mathrm{ha}^{-1}$. In Mietoinen there was also the tendency that at higher coating rates fewer seedlings emerged (data not shown). However, in other treatments and experiments in the following years, seedlings only emerged sporadically and those as an exceptionally early Brassica species greatly attracted flea beetles and the seedlings tended to die within few days after emergence (data not shown). Flea beetle damage is often disproportional in small trial plots.

\section{Potential reasons for failure in seedling emergence}

One of the most likely reasons for poor seedling emergence was lack of soil-to-seed contact as also demonstrated by Kirkland and Johnson (2000) and in laboratory experiments of Willenborg et al. (2004). The broadcast sowing in cereal stubble evidently emphasised this problem. Furthermore, experiments were mainly carried out on clay soils, the top soil of which tends to dry faster than that of organic soils and that does not have such capillarity as sandy and loamy soils. This view was further supported by the finding that when seedlings emerged in broadcast sown plots they were often found in places where the soil surface was concave, slightly broken or in some other way provided better contact with the moist soil.

Temperature was likely to be one of the determining factors for the demonstrated lack of success as seed germination is strongly dependent on it. No signs of emerging seedlings were recorded in Exp. 3, although exceptionally high temperatures of almost $20^{\circ} \mathrm{C}$ occurred during several days in late April 2003, while soil and stubble were still moist. According to results of germination tests, high numbers of seeds in controls and GrowTech Extender ${ }^{\circledR}$ coating treatments were readily able to germinate at such temperatures (Tables 1 and 2). Despite high air temperatures occurring periodically in late April and early May, soil temperatures are, however, still far lower. For example, in late April 2003 when day temperatures rose (Exp. 3), the ground was still frozen just beneath the thawed uppermost soil layers. Nykiforuk and JohnsonFlanagan (1999) indicated that at $6^{\circ} \mathrm{C}$ seeds displayed slow and incomplete germination and poor seedling growth as a result of both thermal and developmental effects. Thus, cold soil may have delayed the onset of germination at the time when moisture was still available. This is also supported by the results from the germination tests at different temperature regimes in the laboratory, which indicated that low temperatures not only resulted in delayed but also in uneven germination (Fig. 1).

To test further the hypothesis of failure caused by poor soil-to-seed contact, the last field experiment (Exp. 4) was arranged by sowing the coated seeds into tilled soil. Despite this, no seedlings emerged in the following spring. Possibly secondary dormancy was induced under unfavourable conditions caused by e.g. moisture stress, freezing temperatures and/or oxygen deficiency caused by too persistent, water-impervious coating (Pekrun et al. 1997). An additional and rather unexpected observation was that despite turnip rape and canola rape seeds remained in the top soil seed bank of the experimental fields, they did not produce volunteer plants to a significant extent later on - either during the following summer, next autumn (which is always characterised by abundant precipitation in Finland), or in the following year(s). This is contrary to the finding that also under northern growing conditions a high proportion of the seeds tends to germinate and emerge as weeds immediately following harvest (Pahkala, unpublished data). Rape seeds are known to persist in soil for up to 10 years (Schlink 1998), but seed predation 
Peltonen-Sainio, P. et al. An alternative sowing time for turnip rape under Finnish growing conditions

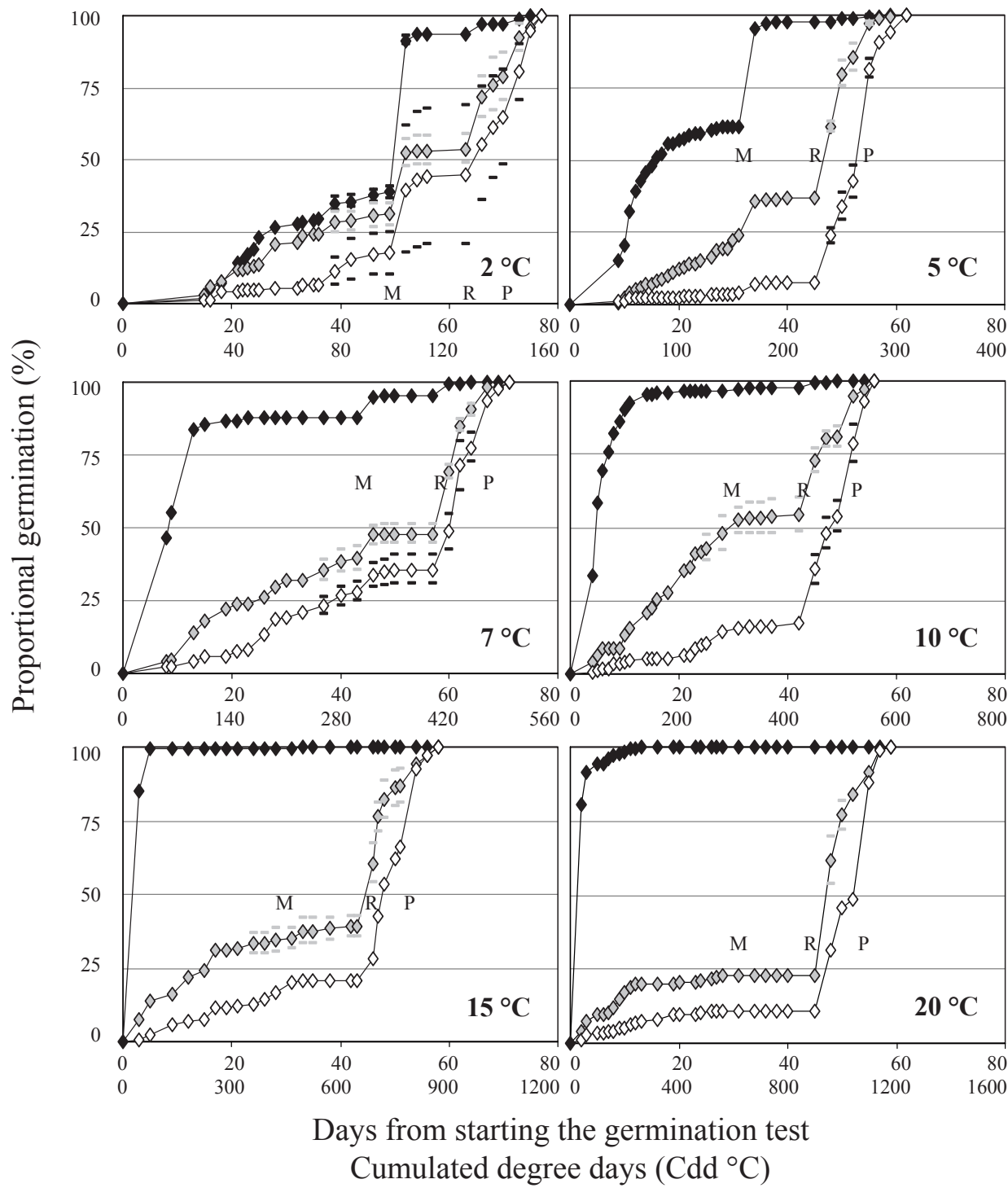

Fig. 1. Effect of temperature on germination in polymer coated turnip rape seeds compared with the control treatment relative to the maximum germination ability for each treatment. Black symbols indicate control, grey symbols seed coating with water impervious Poligen ${ }^{\circledR} \mathrm{WE} 3$ at $4 \%$ and white symbols at $6 \%$. Standard deviation is shown as a horizontal bar next to each symbol. M refers to time when non-germinated seeds were moved to room temperature, $R$ gentle rubbing of seed coats and $P$ pricking of seed with a fine needle. Cumulated degree days corresponding with days from onset of germination tests are calculated by using $0^{\circ} \mathrm{C}$ as a base temperature. 
Vol. 15 (2006): 152-165.

by carabid beetles occurs (Büchs et al. 1991, Honěk and Martinkova 2001). It is also possible that onset of germination in temporarily favourable conditions that rapidly turned unfavourable ended up in early death of the tiny seedlings prior to their being detectable in the field.

To monitor the effects of thickness of waterimpervious polymer coatings on germination and rate of seedling emergence, two laboratory experiments were designed. One of them (Lab-Exp. 1) included seeds that were broadcast sown in the field in non-water-absorbing, highly porous seed bags and were subjected to prevailing conditions. When tested all treatments and controls germinated readily (Table 2). Independent of time of sampling, $50 \%$ of seeds germinated in both controls (Cruiser- and Helix-treated) within three days after placing on blotting paper. This was also the case with water-soluble, freeze sensitive GrowTech Extender ${ }^{\circledR}$ coating. However, first samplings of seeds coated with water-impervious Poligen $₫$-polymer indicated more time was necessary to pierce the coating, and $50 \%$ of the seeds of the total that were able to germinate did so after 11 to 14 days of imbibition when $4 \%$ coating was used. However, it took 55 to 57 days and required some rubbing when $6 \%$ Poligen ${ }^{\circledR}$-coating was used (Table 1). The germination ability in most cases was highest in controls and with 3\% GrowTech Extender ${ }^{\circledR}$ coating. The germination percentage tended to fall the later the sampling time, but no signs of obvious death of seeds were recorded in any of the treatments. Low germination capacity was associated with high frequency of hard seeds recorded at early samplings of Poligen ${ }^{\circledR}$-coated seeds, in particular (Table 1). Straw and snow covering of seeds bags did not greatly alter the ratio between germinating and hard seeds when Poligen ${ }^{\circledR}$-coated. Furthermore, germination ability was enhanced by slightly rubbing the seed coat or pricking with a fine needle only in the two first samplings, both of which were carried out within one month after the winter sowing. Thereafter, higher numbers of Poligen ${ }^{\circledR}$-coated seeds were able to germinate, though not all that were rubbed or pricked. Another interesting finding was that germination of GrowTech Extender ${ }^{\circledR}$ coated seeds did not much differ from that of the control (Table 1). This was also demonstrated in Lab-Exp. 2 (Fig. 2), in which germination did not require frost treatment as also experienced earlier (C. Willenborg, personal communication 15 March 2006).

When seed bags including controls and Poligen $^{\circledR}$ and GrowTech Extender ${ }^{\circledR}$ coated seeds were placed on the soil surface in early spring, similarities between treatments were recorded in germination and numbers of dormant seeds relative to winter sowing (Table 2). The major differences were that seed coat rubbing and pricking did not affect the germination ability. Poligen ${ }^{\circledR}$-coated seeds required far more days to $50 \%$ germination. This clearly demonstrated that Poligen ${ }^{\circledR}$-polymer provided too resistant a coating for early spring sowing, while controls and GrowTech Extender ${ }^{\circledR}$ coated seeds germinated readily (Table 2 ).

It was demonstrated that seeds did not lose their viability in the field to a marked extent when sown at an alternative time. Despite this, there were indications according to the two latest samplings carried out 160 (23 April 2003) and 176 (9 May 2003) days after winter sowing, that some germination in the field occurred when comparing the germinating and hard seeds with those measured from samplings carried out in winter (Table 1). There was also a tendency for less fungal infection of controls than of polymer coated seeds. As seeds coated with GrowTec Extender ${ }^{\circledR}$ were germinated more readily, they faced fewer problems with fungus infections with, however, increasing fungus infection with later sampling time.

The relatively small number of fungus infected, non-viable seeds in germination tests likely demonstrates that there was no particularly marked loss of viability in early sown seeds, knowing that turnip rape is able to yield adequately also when only half the sown seeds germinate and establish a stand (Pahkala et al. 1994). Such a $>50 \%$ germination capacity was recorded frequently (Tables 1 and 2) - with only few exceptions when Poligen ${ }^{\circledR}$ coating was used.

When turnip rape and canola rape were broadcast sown at an alternative time, seeds did not lose their viability to any significant extent, but an alternative reason probably accounts for the poor 


\section{AGRICULTURAL AND FOOD SCIENCE}

Peltonen-Sainio, P. et al. An alternative sowing time for turnip rape under Finnish growing conditions

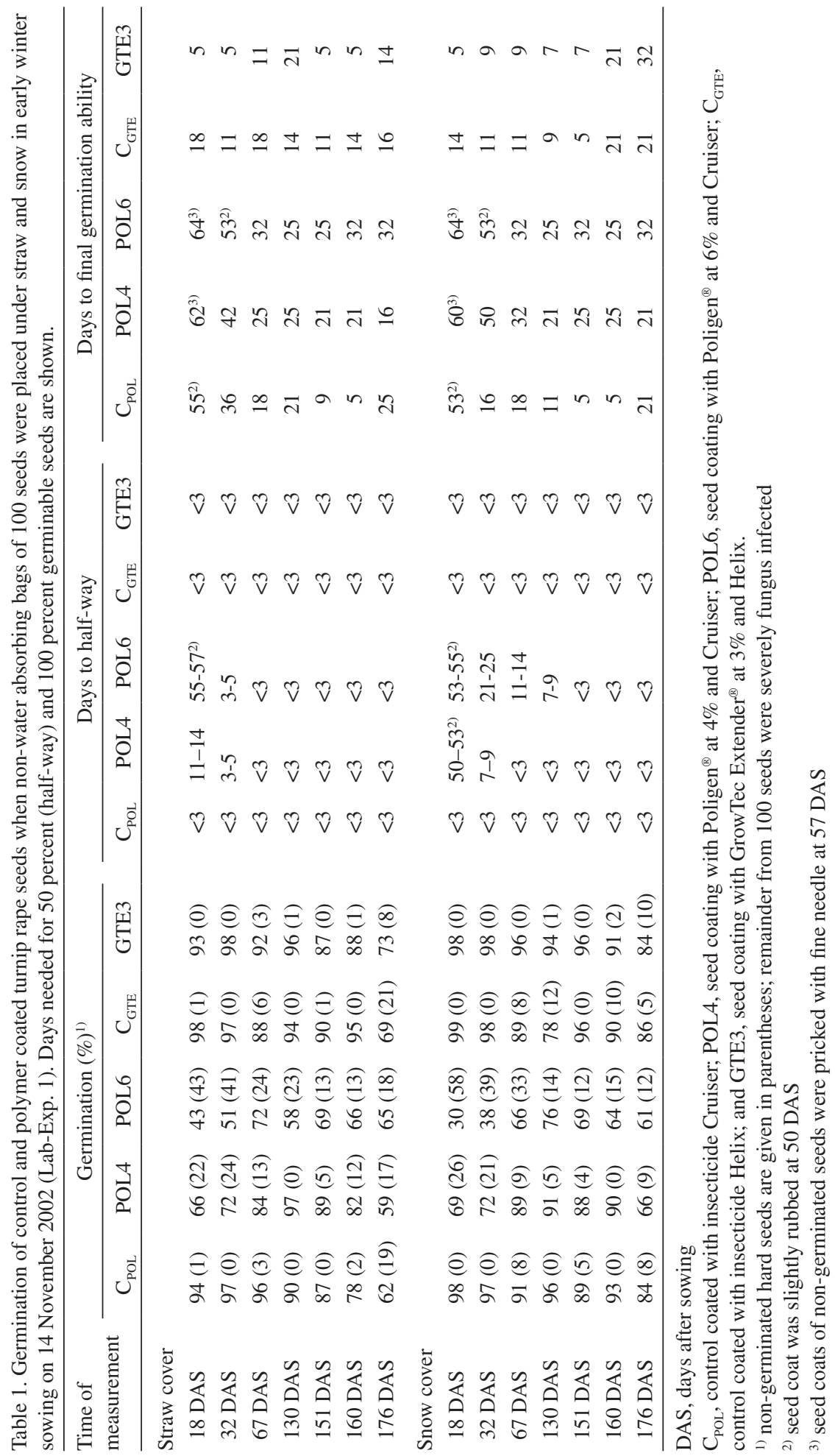


Vol. 15 (2006): 152-165.

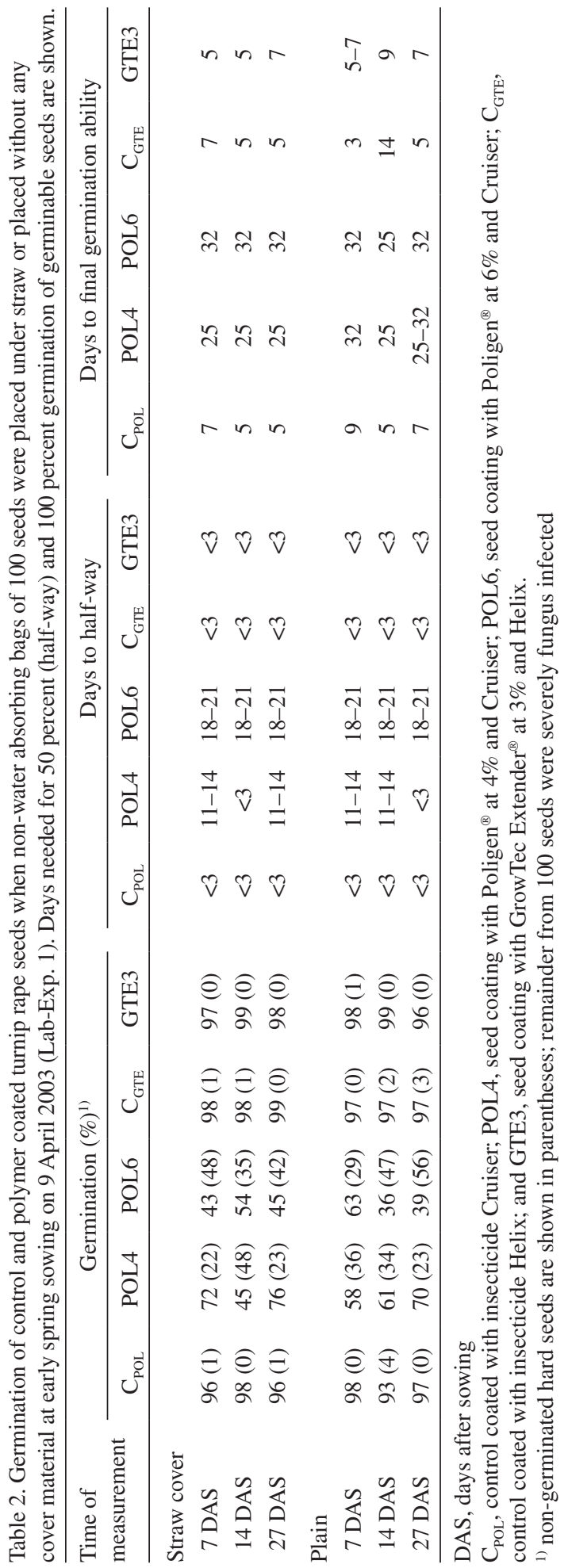

seedling establishment. Another experiment was arranged in the laboratory (Lab-Exp. 2) to monitor the role of temperature on progress of germination in control and coated seeds. Low temperatures retarded germination rate markedly in all treatments and resulted in large within treatment variation especially when Poligen ${ }^{\circledR}$ coated (Figs. 1 and 2, Tables 3 and 4). Also germination remained as low as $36 \%$ in the Poligen ${ }^{\circledR}$ control and 42 in the GrowTec Extender ${ }^{\circledR}$ control at $2^{\circ} \mathrm{C}$, while following transfer to room temperature, about $50 \%$ of the seeds germinated. The higher the temperature, the more readily the seeds germinated. The water impervious polymer coating, Poligen ${ }^{\circledR}$, resulted in high frequency of hard seeds at all temperature regimes and only mechanical treatments, rubbing and pricking, stimulated the seeds to germinate. There was also a tendency for transfer from low temperature to room temperature to stimulate germination. Contrary to Poligen ${ }^{\circledR}$ coating, GrowTec Extender ${ }^{\circledR}$ coated seeds were able to germinate without mechanical treatments (Fig. 2). This Lab-Exp. 2 also indicated that GrowTec Extender ${ }^{\circledR}$ coating does not require frost to liberate the seeds to germinate likewise Willenborg also reported (C. Willenborg, personal communication 15 March 2006). When dynamics of germination were monitored under favourable moisture conditions, on blotting paper, with repeated assessments of germination relative to the maximum, results demonstrated that especially Poligen ${ }^{\circledR}$ seed coatings resulted in uneven germination compared with the control. The only exception was when seeds were germinated at $2^{\circ} \mathrm{C}$, for which also control seeds germinated gradually (Fig. 1). Interestingly, such a low temperature did not, however, result in longer seed dormancy than was recorded in higher temperature treatments.

In conclusion, early broadcast sowing of polymer coated turnip rape or canola rape seed failed to produce plant stands under Finnish growing conditions. In general, high numbers of coated and control seeds were viable until the end of the spring, but seedlings did not emerge in field. The likely reasons for poor success under the northern European growing conditions are poor seed-to-soil contact (especially when a low-cost cropping system was used), but also the overall unfavourable and 
Peltonen-Sainio, P. et al. An alternative sowing time for turnip rape under Finnish growing conditions
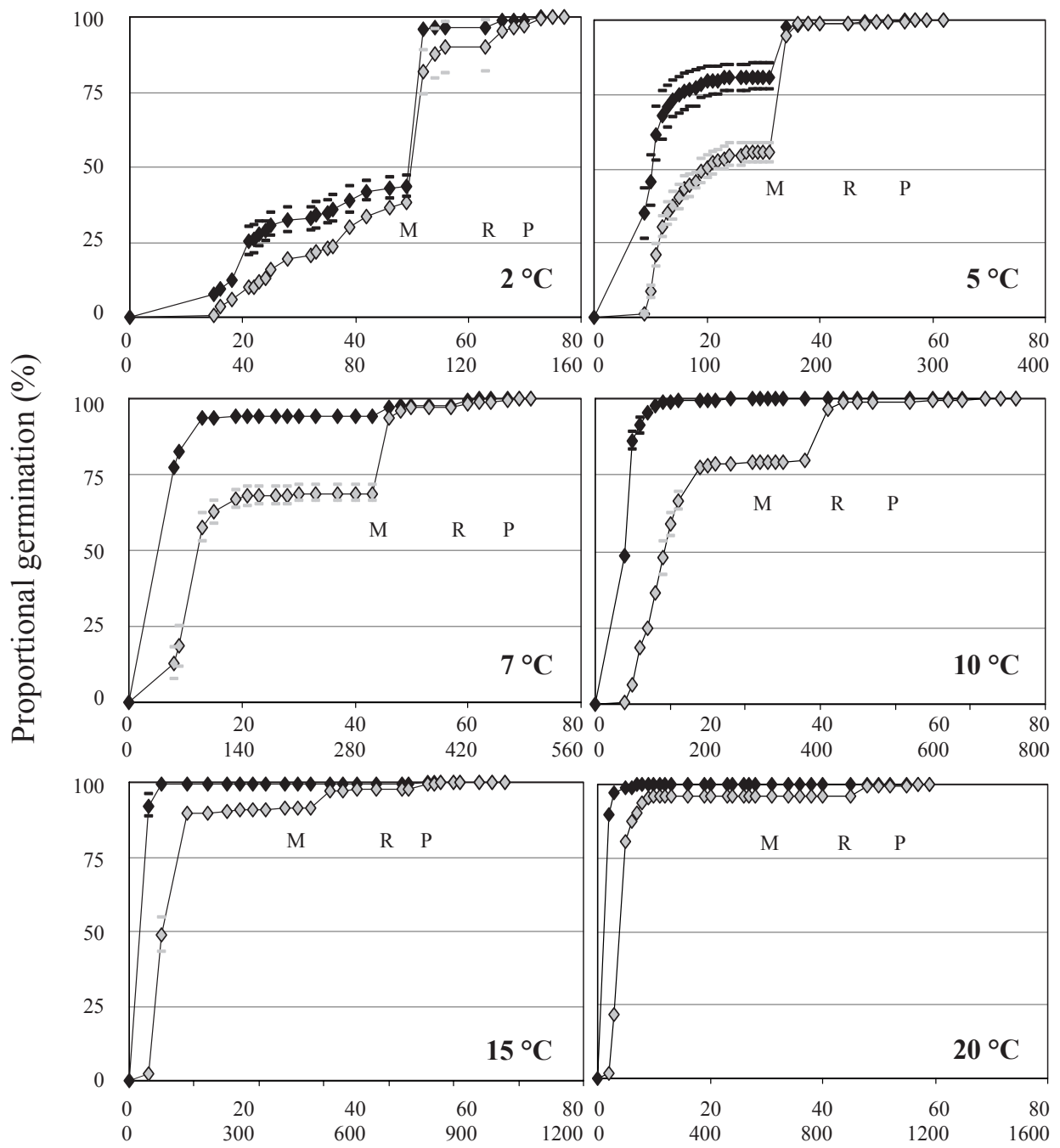

Days from starting the germination test

Cumulated degree days $\left(\mathrm{Cdd}^{\circ} \mathrm{C}\right)$

Fig. 2. Effect of temperature on germination in polymer coated turnip rape seeds compared with the control treatment relative to the maximum germination ability for each treatment. Black symbols indicate control and grey symbols seed coating with GrowTech Extender ${ }^{\circledR}$ at 3\%. Standard deviation is shown as a horizontal bar next to each symbol. M refers to time when non-germinated seeds were moved to room temperature, $\mathrm{R}$ gentle rubbing of seed coats and $\mathrm{P}$ pricking of seed with a fine needle. Cumulated degree days corresponding with days from onset of germination tests are calculated by using $0^{\circ} \mathrm{C}$ as a base temperature. 
Vol. 15 (2006): 152-165.

Table 3. Total germination of control and polymer coated turnip rape seeds under constant $2,5,7,10,15$ and $20^{\circ} \mathrm{C}$ temperature regimes after temperature and mechanical treatments (Lab-Exp. 2). Proportion of abnormal, fungus infected and dormant, hard seeds are shown when measured at the end of the experiment. Standard deviation (SD) shown in parentheses. Control was coated with insecticide Cruiser. Treatment POL4 was coated with Poligen ${ }^{\circledR}$ at $4 \%$ and POL6 at $6 \%$.

\begin{tabular}{|c|c|c|c|c|c|}
\hline & \multirow[t]{2}{*}{ Treatment } & \multirow[t]{2}{*}{ Total germination (\%) } & \multicolumn{3}{|c|}{ Proportion of seeds (\%) } \\
\hline & & & Abnormal & Fungus infected & Hard \\
\hline \multirow[t]{3}{*}{$2^{\circ} \mathrm{C}$} & Control & $94.0(3.0)$ & $1.3(1.2)$ & $0.3(0.6)$ & $4.3(2.9)$ \\
\hline & POL4 & $60.0(13.5)$ & $2.3(0.6)$ & $4.0(2.0)$ & 33.7 (11.7) \\
\hline & POL 6 & $63.7(15.5)$ & $2.0(1.0)$ & $4.3(2.5)$ & $30.0(15.7)$ \\
\hline \multirow[t]{3}{*}{$5^{\circ} \mathrm{C}$} & Control & $93.7(2.1)$ & $3.3(2.3)$ & $1.0(1.2)$ & $2.0(2.5)$ \\
\hline & POL4 & $80.3(3.2)$ & $5.0(1.0)$ & $1.7(1.5)$ & $13.0(4.4)$ \\
\hline & POL 6 & $62.7(2.5)$ & $3.7(0.6)$ & $4.7(0.6)$ & $29.0(3.0)$ \\
\hline \multirow[t]{3}{*}{$7^{\circ} \mathrm{C}$} & Control & $91.7(3.2)$ & $3.0(2.0)$ & $0.7(0.6)$ & $4.7(1.2)$ \\
\hline & POL4 & $68.7(6.7)$ & $4.3(2.5)$ & $1.0(1.0)$ & $26.0(8.2)$ \\
\hline & POL 6 & $42.3(7.8)$ & $4.3(2.3)$ & $1.7(1.5)$ & $51.7(8.6)$ \\
\hline \multirow[t]{3}{*}{$10^{\circ} \mathrm{C}$} & Control & $97.0(1.7)$ & $2.6(1.5)$ & $0.5(0.6)$ & $0.0(0.0)$ \\
\hline & POL4 & $60.0(15.9)$ & $3.3(0.6)$ & $1.0(1.0)$ & $35.7(17.0)$ \\
\hline & POL 6 & $51.3(0.6)$ & $2.7(0.6)$ & $1.7(1.5)$ & $44.3(0.6)$ \\
\hline \multirow[t]{3}{*}{$15^{\circ} \mathrm{C}$} & Control & $93.3(1.2)$ & $4.0(2.6)$ & $1.0(1.0)$ & $1.7(2.1)$ \\
\hline & POL4 & $54.3(11.2)$ & $3.3(1.2)$ & $5.3(2.5)$ & $37.0(7.9)$ \\
\hline & POL6 & 49.7 (5.5) & $5.0(3.0)$ & $4.3(4.5)$ & $41.0(4.6)$ \\
\hline \multirow[t]{3}{*}{$20^{\circ} \mathrm{C}$} & Control & $96.3(1.2)$ & $3.3(0.6)$ & $0.3(0.6)$ & $0.0(0.0)$ \\
\hline & POL4 & $79.3(0.6)$ & $3.7(2.1)$ & $1.7(0.6)$ & $15.3(2.1)$ \\
\hline & POL 6 & 59.7 (11.4) & $3.7(1.2)$ & $7.0(5.3)$ & $29.7(17.5)$ \\
\hline
\end{tabular}

Table 4. Total germination of control and polymer coated turnip rape seeds under constant $2,5,7,10,15$ and $20^{\circ} \mathrm{C}$ temperature regimes after temperature and mechanical treatments (Lab-Exp. 2). Proportion of abnormal, fungus infected and dormant, hard seeds are shown when measured at the end of the experiment. Standard deviation (SD) shown in parentheses. Control was coated with insecticide Helix. Treatment GTE3 was coated with GrowTec Extender ${ }^{\circledR}$ at $3 \%$.

\begin{tabular}{|c|c|c|c|c|c|}
\hline & \multirow[t]{2}{*}{ Treatment } & \multirow[t]{2}{*}{ Total germination (\%) } & \multicolumn{3}{|c|}{ Proportion of seeds (\%) } \\
\hline & & & Abnormal & Fungus infected & Hard \\
\hline \multirow[t]{2}{*}{$2^{\circ} \mathrm{C}$} & Control & $95.0(3.5)$ & $2.3(1.5)$ & $1.0(1.7)$ & $1.7(1.5)$ \\
\hline & GTE3 & $87.3(11.7)$ & $2.7(2.3)$ & $2.0(2.6)$ & $8.0(11.4)$ \\
\hline \multirow[t]{2}{*}{$5^{\circ} \mathrm{C}$} & Control & $99.0(3.0)$ & $0.0(0.0)$ & $1.0(1.0)$ & $0.0(0.0)$ \\
\hline & GTE3 & $95.7(5.8)$ & $3.3(2.2)$ & $1.0(1.0)$ & $0.0(0.0)$ \\
\hline \multirow[t]{2}{*}{$7^{\circ} \mathrm{C}$} & Control & $95.0(1.7)$ & $3.0(1.7)$ & $0.7(0.6)$ & $1.3(2.3)$ \\
\hline & GTE3 & $83.0(15.6)$ & $4.0(3.5)$ & $0.7(0.6)$ & $12.3(18.0)$ \\
\hline \multirow[t]{2}{*}{$10^{\circ} \mathrm{C}$} & Control & $95.3(2.1)$ & $3.0(1.7)$ & $1.0(1.0)$ & $0.7(0.6)$ \\
\hline & GTE3 & $93.0(1.0)$ & $4.0(1.0)$ & $1.7(0.6)$ & $1.3(2.1)$ \\
\hline \multirow[t]{2}{*}{$15^{\circ} \mathrm{C}$} & Control & $89.3(8.1)$ & $3.7(1.5)$ & $1.7(2.1)$ & $5.3(7.6)$ \\
\hline & GTE3 & $89.7(2.9)$ & $8.7(3.2)$ & $1.3(0.6)$ & $0.3(0.6)$ \\
\hline \multirow[t]{2}{*}{$20^{\circ} \mathrm{C}$} & Control & $94.0(1.7)$ & $4.3(2.5)$ & $1.7(1.2)$ & $0.0(0.0)$ \\
\hline & GTE3 & $91.7(3.8)$ & $6.3(2.5)$ & $0.7(1.2)$ & $1.3(1.5)$ \\
\hline
\end{tabular}


Peltonen-Sainio, P. et al. An alternative sowing time for turnip rape under Finnish growing conditions

harsh conditions (temperature regime, possible spring frosts, early flea beetle attack) for such a technology.

Acknowledgement. The authors are grateful for Kauko Kyläsorri, Matti Matilainen, Pirjo Mäntyvaara, Marja Kujala and Jaana Grahn at MTT Agrifood Research Finland for their assistance in organising the experiments and making measurements. The study was financed by the Ministry of Agriculture and Forestry, MTT Agrifood Research Finland and Kemira GrowHow Oyj.

\section{References}

Büchs, W., Heimbach, U. \& Czarnecki, E. 1991. Effect of different rape seed dressings on carabid beetles: laboratory and semifield tests. Gesunde Pflanzen 43: 299306.

Honěk, A. \& Martinkova, Z. 2001. Aggregation of ground beetles (Carabidae, Coleoptera) on winter rape seeds dispersed on the ground. Plant Protection Science 37: 97-102.

Johnson, E.N. \& Ferguson, T. 2004. Polymer seed coating of early- and late-fall-seeded herbicide-tolerant canola (Brassica napus L.) cultivars. Canadian Journal of Plant Science 84: 971-979.

Johnson, E.N., Miller, P.R., Blackshaw, R.E., Gan, Y., Harker, K.N., Clayton, G.W., Kephart, K.D., Wichman, D.M., Topinka, K. \& Kirkland, K.J. 2004. Seeding date and polymer seed coating effects on plant establishment and yield of fall-seeded canola in the Northern Great Plains. Canadian Journal of Plant Science 84: 955963.

Karamanos, R.E., Harapiak, J. \& Flore, N.A. 2002. Fall and early spring seeding of canola (Brassica napus L.) using different methods of seeding and phosphorus placement. Canadian Journal of Plant Science 82: 2126.

Kirkland, K.J. \& Johnson, E.N. 2000. Alternative seeding dates (fall and April) affect Brassica napus canola yield and quality. Canadian Journal of Plant Science 80: 713-719.

Locquenghien, von, K.H., Engelhardt, K., Kleinback, E. \& Müller, M.W. 2001. Coated fertilizer granules. U.S. Patent 6187 074. Date issued: 13 February.

Nykiforuk, C.L. \& Johnson-Flanagan, A.M. 1999. Storage reserve mobilization during low temperature germination and early seedling growth in Brassica napus. Plant Physiology and Biochemistry 37: 939-947.

Pahkala, K. \& Sankari, H. 2001. Seed loss as a result of pod shatter in spring rape and spring turnip rape in Finland. Agricultural and Food Science in Finland 10: 209-216.

Pahkala, K., Laakso, I. \& Hovinen, S. 1991. The effect of frost treatment on turnip rape seedlings, ripening of seeds and their fatty acid composition. Proceedings GCIRC Rapeseed Congress 1991. 6: 1749-1753.

Pahkala, K., Sankari, H. \& Ketoja, E. 1994. The relation between stand density and the structure of spring rape (Brassica napus L.). Journal of Agronomy and Crop Science 172: 269-278.

Pekrun, C., Lutman, P.J.W. \& Baeumer, K. 1997. Induction of secondary dormancy in rape seeds (Brassica napus L.) by prolonged imbibition under conditions of water stress or oxygen deficiency in darkness. European Journal of Agronomy 6: 245-255.

Salonen, J., Hyvönen, T. \& Jalli, H. 2001. Weed flora in organically grown spring cereals in Finland. Agricultural and Food Science in Finland 10: 231-242.

Schlink, S. 1998. 10 years survival of rape seed (Brassica napus L.) in soil. Journal of Plant Disease and Protection 16: 169-172.

Willenborg, C.H., Gulden, R.H., Johnson, E.N. \& Shirtliffe, S.J. 2004. Germination characteristics of polymer-coated canola (Brassica napus L.) seeds subjected to moisture stress at different temperatures. Agronomy Journal 96: 786-791.

Zaychuk, K.S. \& Enders, N.H. 2001. Water soluble, freeze sensitive seed coatings. U.S. Patent 6230 438. Date issued: 15 May. 


\title{
SELOSTUS
}

\section{Rypsin ja rapsin kylvöjen aikaistaminen siemenpinnoitteiden avulla ei toimi Suomen kasvuoloissa}

\author{
Pirjo Peltonen-Sainio, Hannu Känkänen, Katri Pahkala, Yrjö Salo, Erja Huusela-Veistola ja Jari Peltonen \\ Maa- ja elintarviketalouden tutkimuskeskus ja Kemira GrowHow Oyj
}

Kanadassa on kehitetty kustannuksia säästävä ja työhuippuja tasaava vaihtoehtoinen rapsin kylvömenetelmä. Patentoidussa menetelmässä rapsin siemen pinnoitetaan polymeerilla (GrowTec Extender ${ }^{\circledR}$ ), joka on vesiliukoinen ja herkkä pakkaselle. Menetelmässä (carrier technology) kevätmuotoisen rapsin pinnoitetut siemenet kylvetään myöhään syksyllä, ennen pakkasten tuloa. Pinnoite imee itseensä vettä, luovuttamatta sitä rapsin siemenelle. Pakkasten tultua pinnoite jäätyy ja särkyy, jolloin siemen voi kostua talven väistyttyä. Näin varmistetaan, että syksyllä kylvetty siemen ei idä ennen aikojaan vaan vasta keväällä. Tämä tapahtuu kuitenkin selvästi kevätkylvöjä aikaisemmin, joten satoisuus paranee - varsinkin, kun näin onnistutaan välttämään kukinnan ja siementen muodostumisen ajoittuminen pahimpaan helle- ja kuivuusaikaan.

Menetelmä on kiinnostava myös Suomen lähtökohdista. Syysmuotoisten öljykasvien talvehtimisongelmat ja -epävarmuus ovat estäneet viljelyn laajenemisen, vaikka tiedetään, että onnistuessaan tämä mahdollistaisi satoisuuden paranemisen. Myös kevätkuivuuden aiheuttamat taimettumisongelmat voitaisiin mahdollisesti ohittaa.

Teimme siemenpinnoitekokeita pellolla ja laboratoriossa. Kanadalaisten patentoiman pinnoitteen lisäksi tutkimme lannoiterakeiden pinnalla käytettävän Poligen $^{\circledR}$-polymeerin soveltuvuutta siemenpinnoitteeksi. Koesarjoissa oli useimmiten rypsin ohella rapsi, ja kylvösiemen pinnoitettiin usealla Poligen ${ }^{\circledR}$-polymeerin ainemäärällä. GrowTech Extender ${ }^{\circledR}$-pinnoitetta käytettiin vain yhtä pitoisuutta Kanadan mallin mukaisesti.

Tutkimuksissa tähdättiin menetelmään, jossa pinnoitetun siemenen kylvö tehtiin muokkaamattomaan peltoon, suoraan viljan sänkeen, ja josta rikkakasvit torjuttiin jo ennalta totaalitorjuntana syksyn aikana. Koesarjat kylvettiin Jokioisiin ja Mietoisiin erilaisin kokoonpanoin kolmen vuoden aikana. Talvea vasten tehdyn kylvön rinnalla kokeiltiin myös hyvin varhaista kevätkylvöä, yöpakkasten yhä esiintyessä.
Ensimmäisenä vuonna kasvustot taimettuivat parhaiten, joskin jäivät parhaimmillaankin liian harvoiksi. Seuraavien vuosien kokeissa vain satunnaiset yksilöt taimettuivat. Aikaisin taimettuneiden rypsien ja rapsien kohtaloksi koituivat kuitenkin ankarat kirppavahingot. Poikkeuksellisen aikaisina Brassica-kasveina ne houkuttelivat kirppoja niin, että taimet tuhoutuivat heti pian havaituksi tulonsa jälkeen. Ensimmäisenä koevuotena, kun taimimäärä oli paikoitellen kohtuullinen, turvauduttiin toistuviin torjuntakäsittelyihin.

Menetelmä ei toiminut. Suurimpana syynä epäonnistumiseen pidimme siemenen huonoa kontaktia kosteaan maahan. Tätä tuki havainto, että taimia esiintyi eniten niissä kohdissa koeruutua, jossa maa oli painautunut, sen pinta oli rikkoutunut tai siemen oli muuten päässyt parempaan kontaktiin maan kanssa. Toisaalta tätä tulkintaa vastaan on näyttö, että siemenet eivät itäneet havaittavasti myöhemmin kasvukauden aikana tai syksyllä syyssateiden turvin, vaikka näin käy esimerkiksi puinnin yhteydessä varisseille rypsin siemenille. Tämän vuoksi selvitimme kylvettyjen, pinnoitettujen siementen kohtaloa pellossa - niin epäonnistumisen syyn ymmärtämiseksi kuin menetelmän mahdollisen edelleen kehittämisen tueksi. Tämä perustui laboratoriossa tehtäviin idätyskoesarjoihin, joissa toisessa tutkittiin pellolta kerättyjen siemennäytteiden ja toisessa kylvöissä käytetyn siemenen itämisdynamiikkaa.

Lisätutkimukset osoittivat, että rypsin siemenet eivät menettäneet talven aikana itämiskykyään, joten syynä menetelmän toimimattomuuteen ei ollut siementen tuhoutuminen. Laboratoriossa tehdyt idätykset osoittivat lisäksi, että GrowTech Extender ${ }^{\circledR}$-pinnoite vapautti siemenen hyvin nopeasti, jo aivan talven alussa, vedeltä suojaavasta vaipasta. Pinnoitemäärän lisääminen viivästytti itämään lähtöä, ja vaikutus korostui alhaisissa lämpötiloissa. Menetelmän toimimattomuuden keskeisin syy oli siemenen huono kontakti maan kanssa. 